\title{
Tõenduspõhisest eripedagoogikast
}

\author{
Jaan Kõrgesaara \\ a Tartu Ülikool
}

\begin{abstract}
Mitchell, D. (2014). What really works in special and inclusive education: Using evidence-based teaching strategies (2nd ed.). London, New York: Routledge.
\end{abstract}

Eesti näib astuvat ühte jalga David Mitchelli ja teiste tõenduspõhise pedagoogika edendajatega. Mitchell oli peakõneleja 2015. aasta mais Tartus toimunud konverentsil ning temalt pärineb üks kahest praegusesse erinumbrisse tellitud artiklist. Ehk ei lähe liiale arvustada siinkohal ka selle maakera kuklapoole autori tähtteost „What really works in special and inclusive education: Using evidence-based teaching strategies” („Mis tõepoolest toimib eri- ja kaasavas pedagoogikas: kasutades tõenduspõhiseid õpetamisviise"). Teose kõrget staatust näitavad tõlked taani, rootsi, poola, hollandi, jaapani ja korea keelde ning külluslik veebikajastus. Menuki kolmandat väljaannet võib oodata aastal 2018.

Vahemärkuse korras lisatagu, et kirjastuse andmeil eristatakse sama autori käesoleva aasta oktoobris ilmunud raamatus „Diversities in education: Effective ways to reach all learners“ („Mitmekesisus hariduses: mõjus viis jõuda iga õppijani“) viit liiki mitmekesisust: sugupool, klassikuuluvus koos sotsiaal-majandusliku staatusega, rass ja etnilisus koos kultuuriga, veendumused ja religioon. Muu hulgas küsitakse, miks me austame mitmekesisust ja inimõigusi ning kuidas kaasav haridus kohaneb mitmekesisusega. Samuti jagatakse raamatus soovitusi hariduse edendamise kohta.

Järgides Melbourne’i ülikooli professori John Hattie kasvatusteaduse valdkonna menuki „Visible learning” („Silmanähtav õppimine”, 2009) kui metauuringute ülevaateteose ambitsioone, analüüsib ja esitleb Uus-Meremaa Canterbury ülikooli professor David Mitchell raamatus „What really works ...” pealt kahtekümmet „tõendatult õpisoodsat strateegiat”. Sõna strateegia võib olenevalt kontekstist tõlkida kas sekkumiseks, lähenemiseks, tehnikaks ja/või metoodikaks. Mõni sekkumine on servapidi seotud kaasava õppega, kuid kindlasti on nad kõik rakendatavad omaette. Seejuures 
ei erista Mitchell tõendus- ja uurimuspõhisust (ingl evidence-based ja research-based).

Peale Hattie andmete võttis Mitchell vaatluse alla veel umbes 2000 uurimust, millest enamik pärineb USAst ja Ühendkuningriigist, lisaks veel 14 arenenud riigist. Andmeid analüüsides pidas ta silmas andmekogumise ja -töötluse vastavust sekkumispuhustele teadusstandarditele, nii sekkumise enda autentsust kui ka selle hindamise asjakohasust (ingl fidelity), muutujate hoidmist kontrolli all, sekkumise kõrvalnähtude vastuvõetavust, uuringu järelkontrolli asjakohasust ja kordamist ning sekkumise kulutõhusust. Metaanalüüsiga otsis autor veenvalt mõjusaid sekkumisviise, lugedes väga heaks sekkumistulemuse, mille mõju suurus (ingl effect size, edaspidi $M S$ ) oli üle 0,7, kuid pidades heaks ka tulemusi vahemikus 0,3-0,7. Enamik mõjusatest sekkumisviisidest toetub peale soodsate katseandmete ka soliidsele teooriale.

Erinevalt USA tuntud ja tunnustatud avalikust andmebaasist What Works Clearinghouse (WWC) analüüsib ja esitleb Mitchell ka ebaesinduslikke, sh üksikjuhtumipõhiseid kvaasieksperimente ja kvalitatiivseid uuringuid. Mitchell osutab neljale asjaolule, miks ei olda rahul What Works Clearinghouse'i eksklusiivse toetumisega esindusliku juhuvalimiga katselistele uurimustele (ingl randomized controlled trials, RCT). Mitchell avaldab lootust, et vähem esinduslike uurimuste kaasamine võimaldab siiski usaldusväärselt laiendada tõenduspõhiselt mõjusaks tunnistatud sekkumisviiside ringi. Pürgimine kesktee poole kajastub ka pragmaatiliselt eklektilises suhtumises erinevatesse õpiteooriatesse, sest ta toetub iga lähenemisviisi puhul just nimelt sellega sobivale teooriale.

Teose alguses esitatakse õppimise ja õpetamise plokkskeem, iga alateema juures osutatakse avatavale plokkskeemi elemendile. Mitchelli „What really works ..." liigendus peatükkideks teenib loetavuse huve: osaliselt kattuvad teemad on liigendatud väiksemateks ,justnagu teemadeks”, rõhutamaks nende kaalu tegelikus õppes ja kasvatuses. Peatükid on omakorda jaotatud poole- kuni kaheleheküljelisteks lühipaladeks, mida eristavad alapealkirjad, šriftid ja raamid, välja on toodud oluline, kokkuvõtted ja viited. Alustatakse vaatlusaluse strateegia lühiesitlusest, seejärel tutvustatakse käsitluse aluseks olevat ideed ja tuuakse riburada pidi elulähedasi näiteid koolipraktikast. Näidete järel tsiteeritakse metauurimuste andmeid lähenemisviisi mõjukuse kohta ja meenutatakse strateegia rakendamisega kaasneda võivaid ohtusid. Iga peatükk sobiks käsitletava teema avamiseks Wikipedias. Mõnel juhul, nt direct instruction'i näitel, on Wikipedia käsitlus Mitchellile arvestatav konkurent. Samas jääb lähenemisviiside kompaktne esitamine iseväärtuseks vähemalt kahel põhjusel. Esiteks tuleb selgelt esile mallide endi rohkus, 
sisemine nüansirikkus, sh võimaluste ja piirangute laiali laotumine, iseäranis paberraamatus. Teine põhjus on tööriistastu spetsiifilisus, mille korral tuleb arvestada nii õpilase erivajadusi / individuaalset eripära, sekkumisressursi olemasolu ja kvalifikatsiooni, sh kasutada olevat tööjõudu ja -aega, kui ka konteksti (ajajaotus, ruumid, seadmed).

Umbkaudu 20 sisuldasa osaliselt kattuvat mõjusat lähenemisviisi jaotuvad põhijoontes nelja rühma: õpikontekst, tunnetusstrateegiad, biheivioristlikud käsitlusviisid, kooliülesed lähenemisviisid ja ametkondade koostöö. Õpikontekstina vaadeldakse a) rühma(na)-õpet, sh taseme- ja eritasemerühmade plusse ja miinuseid, Hattie $M S=0,59$; b) õpetamist eakaaslaste poolt, Hattie $M S=0,55 ; \mathrm{c}$ ) prosotsiaalsete oskuste ehk positiivse suhtluse harjutamist, Hattie $M S=0,40$; d) koostöö(s) õpetamist, Hattie $M S=0,19$; e) õppurite vanemate kaasamist, Hattie $M S=0,8$ (vanemlikud ootused). Seevastu tunnetusstrateegiatena käsitletakse a) kognitiivsete, tunnetus- või mõtlemisoskuste õpetamist, Hattie $M S=0,69$; b) enesereguleeritud õppimist, Hattie $M S=0,64$ (eneseküsitlemine ja isesõnastamine); c) mnemotehnikat/mnemoonikat, $M S=1,62$; d) ajas liigendatud kordamist ja harjutamist, Hattie $M S=0,71$ (liigendatud harjutamine); e) pöördõpet (ingl reciprocal teaching), Hattie $M S=0,74$.

Käitumuslikud lähenemisviisid on üks neljast tõhusaimast sekkumisest Mitchelli loendis: mõjukuse suurus sotsiaalsete oskuste vallas on 0,69 ja akadeemiliste oskuste vallas 1,57 . Teised kolm on mnemoonika, loetu mõistmine ja otsene õpe. Eraldi vaadeldakse käitumise funktsionaalanalüüsi. Ootuspäraselt on sekkumine iseäranis kohane ja mõjus emotsionaalsete ja käitumisraskuste korral, kahandades ühe hiljutise metaanalüüsi järgi ebasoovitavat käitumist 70\%. Eraldi käsitletakse raamatus ka kognitiivset käitumisravi ja otsest õpet nii $\mathrm{DI}^{\mathrm{nt}}$ kui ka laiemas tähenduses (ingl precision, explicit, structured, systematic teaching/instruction; Hattie $M S$ = 0,59). Mitchell vaidlustab $\mathrm{DI}^{\mathrm{m}}$ autorite purismi ehk nõude rakendada lähenemisviisi autentselt, pidades vajaminevaid materjale, koolitust ja seiret mõnele koolile üle jõu kalliks. Ühtlasi leiab Mitchell, et laiemas tähenduses aitab samu sihte saavutada see, kui piisavalt tempokat õpet kombineeritakse maksimaalsete vastamisvõimaluste, toestamise (ingl scaffolding), sagedase hindamise ja omandatud oskuste sihipärase rakendamisega (lk 180).

Viimase, küllalt eklektilise strateegiate rühma moodustavad a) kujundav hindamine ja tagasisidestamine, Hattie $M S=0,90$ (kujundav hindamine), $M S=0,73$ (tagasisidestamine); b) tugitehnoloogiad; c) augmentatiiv- ja alternatiivkommunikatsioon; d) foneemiteadlikkuse õpe ja fonemaatiline lugemaõpetamine, Hattie $M S=0,73$; e) soodus füüsiline õpikeskkond (siseruumis); f) universaaldisain; g) nn sekkumisvastus (USAs response to inter- 
vention ehk RTI, Ühendkuningriigis graduated response model); h) turvalise, positiivse ja motiveeriva psühhokliima kujundamine klassis, Hattie $M S=0,52$ (hästi korraldatud klass), $M S=0,53$ (klassi ühtekuuluvustunne), $M S=0,72$ (õpetaja õpilaskesksus); i) mitmeastmeline ülekooline lähenemisviis käitumisprobleemide minimeerimiseks (koolikultuuri ülesehitamine, ülekoolilise käitumistoe rakendamine, kõikidele õppuritele edukogemuse tagamine); j) asutuste ja ametkondade vaheline koostöö; k) kõiki kaasav haridus ehk õppesisu (ingl programme), metoodika, hindamise, tajutavuse/ juurdepääsetavuse kohandamine kõikidele sobivaks.

Kõiki kaasav haridus olla paljukomponendiline megastrateegia, mille aluseks on a) lootus, et HEV-õppurid ei edene mitte ainult akadeemiliselt, vaid ka sotsiaalselt, mistõttu paraneb nende enesehinnang; b) lootus, et süveneb tavaõppurite positiivne hoiak inimliku mitmekesisuse suhtes; c) odavus võrreldes lahusõppe ja sellega kaasneva transpordiga. Mitchell loetleb üksteist põhjust, miks püsib lõhe kaasamispõhimõtte ja tegelikkuse vahel (ingl policy-practice gap). Nende hulka kuulub lapsevanemate vastuseis, nt Austraalias toetavad vanemad teenuste kontiinuumi (st mitte lihtsalt kaasamist), milles on olulisel kohal nõuetekohased erikoolid.

Mitchell möönab, et hämmastavalt rohkearvuliste kaasavat haridust propageerivate uurimuste seast pole kerge leida usaldusväärseid allikaid. Osa materjali on aegunud või jääb liialt oluspetsiifiliseks. Paljudes uurimustes võrreldakse vaid õppija õppekohta/paigutust (ingl placement), süüvimata õppesse endasse, teised uurimused on uurimismetoodiliselt küündimatud. Alles jäävast arvestatavast uurimismaterjalist leiab vastuolulisi tulemusi, sedastatakse ka positiivne mõju või mistahes mõju puudumine. Mitchell lõpetab oma tõenduspõhisusest kantud teose mõneti vastuoluliselt, väljendades usku, et korralikult rakendatult võib kaasav haridus tuua kõikidele õpilastele nii akadeemilist kui ka sotsiaalset kasu (lk 311), Hattie MS = 0,28 (peavoolu-lähenemine, ingl mainstreaming). Mitchell nimetab suurima ohuna kaasamisidee poolikut, pealiskaudset rakendamist kõrvuti õppuri huvide eiramisega, mida tehakse põhimõtte nimel.

Teose lõpuosast leiame juhtumikirjeldusliku üleskutse õppida Soome kogemusest. Mitchelli hinnangul on Soome haridusele taganud edu PISA testis viis tegurit: tasakaal keskse ja hajutatud juhtimise vahel, head õpetajad, juhindumine põhimõttest tagada haridus kõigile, heal tasemel varajane (sh koolieelne) sekkumine ning HEV-õpilastele kättesaadav ja sobiv (ingl comprehensive) tugi (lk 322). Viimases peatükis esitatakse metastrateegiana või kõiki eelnimetatud meetodeid ühitava katuspõhimõttena nõue tagada õppimisvõimalused piisava hulga kvaliteetselt sisustatud aja jooksul. HEV-õppurite puhul avaldub võimalus õppida esiteks juurdepääsus 
haridusele, teiseks õppeaasta tuumõppekava kättesaadavuses, kolmandaks kõrgetasemelises õppes. Viimane oluline nõue on anda piisavalt aega adekvaatseks ja aktiivseks õppimiseks. Õpetamise kvaliteedi $M S=0,84$, Hattie $M S=0,38$ (ülesandega tegelemise aeg, ingl time on task).

Mitchell esitab kaasava hariduse (ingl inclusive education, IE) valemi: $\mathrm{IE}=\mathrm{P}+\mathrm{V}+5 \mathrm{As}+\mathrm{S}+\mathrm{R}+\mathrm{L}$, milles $\mathrm{P}=$ placement (sobiva õppeasutuse, klassi või rühma tähenduses), $\mathrm{V}=$ vision (sihti seadev kujutlus), $\mathrm{A}=$ adapted curriculum (kohandatud opppekava), $\mathrm{A}=$ adapted assessment (kohandatud hindamine), $\mathrm{A}=$ adapted teaching (kohandatud õpetamine); $\mathrm{A}=$ acceptance (omaksvõtt), $\mathrm{A}=$ access (juurdepääs), $\mathrm{S}=$ support (tugi), $\mathrm{R}=$ resources (inimesed, ruum, aeg, raha) ja $\mathrm{L}=$ leadership (eestvedamine). Eduks vajab kaasav haridus kõikide valemi komponentide toimimist.

David Mitchell osutab, et kaasav haridus võib õigesti rakendatuna tuua kõikidele õpilastele õpiedu ja kujundada soodsaid inimsuhteid. Peatükkide elulähedastest nimetustest ei tohi lasta end eksitada, sest enamik mingis aspektis mõjukaid tõenduspõhiseid lähenemisviise kätkeb endas täpseid toimimisjuhiseid, paljud eeldavad kogu personali ühisrinnet. Nõudlikud ehk töömahukad sekkumisviisid on kallid, nt meilegi tuttav Ivar Lovaasi autismiteraapia. Teisisõnu raiskab mõjusaks osutunud sekkumisviiside ligikaudne, enam-vähem-rakendamine aega ja annab valesignaali sekkumise mõjutusest ${ }^{2}$. Tõsi, püüdes esitada kõrvuti nii elupraktikat kui ka kitsa suunitlusega tõenduspõhiseid sekkumisviise, hägustab autor veidi autentsussõnumit. Raamatu kirjastaja Routledge käitab raamatu veebituge, kus iga kool saab hinnata, kuivõrd nad ühte või teist sekkumist rakendavad (vt routledgetextbooks.com/textbooks/_author/mitchell-9780415623230/).

Mitchell möönab, et arenenud riikidest pärinevad andmed ja sekkumisviisid ei pruugi sobida vaesematesse oludesse. Ida-Euroopa suhteliselt tagasihoidlikes oludes on senini vähe leida eri- või tavakoole, milles ressursinappus ei piiraks kirjeldatuga võrreldavate sekkumisviiside rakendamist. Soovi(ta)des kasutada teost tõenduspõhiste sekkumisviiside käsiraamatuna, tuleb sellest piirangust endale aru anda. Vähemal määral piirab nende rakendamist ingliskeelse ruumi domineerimine. Muidugi oleks parem toetuda meie oludesse sobivamatele teadustekstidele, mis on pärit näiteks sellistest eneseküllastest mitte-ingliskeelsetest kasvatusteadusruumidest nagu Venemaa ja Poola, mille mentaliteet ja elujärg meenutavad meie oma. Õnneks leidub teoses mõni näide Saksamaa ja Hollandi kohta,

„... as with any of the strategies outlined in this book, a lack of fidelity of implementation can jeopardize its success" (lk 249); märkus puudutab RTId, Eesti mõistes sekkumise kolmeastmelisust. 
mis on meiega kasvatusmentaliteedilt sarnased. Paraku saab näiteid tuua vaid eeldusel, et samu lähenemisviise neis riikides piisavalt esinduslikult ka rakendatakse ja uuritakse. Veel üks Mitchelli pragmaatilis-eklektilise ehk kirik-keset-küla-käsitlusega kaasnev probleem on nii teooria- kui ka tõenduspõhisuse laiendamine hämaraladele. Kes tahab, see usub ja rakendab ka seda, mille mõjusus pole veenvalt tõendatud. Inimese elu pole ju kaalul!

Raamatus on tihedalt pedagoogika oskussõnu, millest paljude puudumine meie vastses haridussõnastikus sundis siinkirjutajat tegelema sõnaloomega nii lähenemisviiside kui ka metauuringute esitlemiseks. Et võimalikud ebaõnnestumised ei kinnistuks, soovitan nii EKI kui ka WIKI-artiklite koostajail kasutada väljaannet asjakohase, definitsiooniküllase ja mugava allikmaterjalina.

Raamatu ühes napis, kuid sisukas peatükis vaadeldakse ülla kaasamisidee ajaloolist kujunemist, jätmata viitamata asjaomastele vastuoludele. Põhirõhk on osutusel, et tõetruult (ingl high fidelity) rakendatuna võib ühe tõenduspõhise sekkumisega edukalt ületada ühte, teisega teist ja kolmandaga kolmandat erivajadust, sõltumata isiku füüsilisest ja inimkeskkonna asukohast. Tuleb loota, et sõnum mõjusa sekkumise oskustööjõumahukusest leiab tee ka nende foorumite juurde, kus on seni keskendutud õppeasutuse omandivormile, nimele ja asukohale ning HEV-õppe kulukusele, jättes sekkumise ilu ja valu pedagoogi koormuse, veendumuste, üldpädevuse ja loovuse kanda. Rakendamise edukus sõltub lähenemisviiside omaksvõtust ja arendustest eri ainete õppes, alustades lugema õpetamisest. 2015. aasta konverentsil tehti üleskutseid tagada Eestiski korralik õpe raskemate puuetega õppuritele ning mitte rutata ette oma võimalustest. Eeskujusid on (nt Viimsi, Kivilinna, Mäetaguse kool), kuid kohati jääb suutlikkus tahtmisest kaugele maha.

Raske on ennustada, kas Mitchelli teos aitab ühendada hariduspoliitikat ja praktikat. Kindlasti peaks diskussioonides ja õpetajakoolituses pälvima tähelepanu Mitchelli katse ehitada sildu ja purdeid üle tõendus- ja kogemuspõhisuse lõhe. Kas paberraamatu terviklikkus kaalub üles rikkalike digimaterjalide liigendatuse ja sirvitavuse (WWC, kuid mitte ainult), on peaaegu et raskeim küsimus. Ent müügil on ka teose digiversioon! 